\title{
Implementasi Pendidikan Karakter Dalam Membina Sikap Disiplin Peserta Didik di Taman Pendidikan Al-Qur'an (TPQ) Ihsan Muhammadiyah Kota Padang
}

Mia Hastarina ${ }^{1}$, Murniyetti ${ }^{2}$

miahastarina0210@gmail.com ${ }^{1}$, murniyetti21@gmail.com² Universitas Negeri Padang 1,2

\begin{tabular}{l}
\hline ARTICLE INFO \\
\hline Article history: \\
Received 5 Agustus 2021 \\
Revised 24 Agustus 2021 \\
Accepted 31 Agustus \\
2021 \\
\hline Keywords: \\
Pendidikan Karakter, \\
Sikap Disiplin, Faktor \\
Pendukung dan \\
Penghambat.
\end{tabular}

Clonflict of Interest:

None

Funding:

None

\section{ABSTRACT}

Penelitian ini bertujuan mengetahui
pelaksanaan, evaluasi, faktor pendukung dan penghambat pendidikan karakter dalam membina sikap disiplin peserta didik di TPQ Ihsan Muhammadiyah Kota Padang. Penelitian ini termasuk penelitian kualitatif dengan teknik mengumpulkan data wawancara, observasi dan dokumentasi. Teknik analisis data yang digunakan deduktif. Artikel ini membahas tentang: (a) pelaksanaan pendidikan karakter dalam membina sikap disiplin peserta didik dilakukan dengan peraturan yang harus ditaati, pemberian nasihat, dan sanksi, (b) evaluasi pendidikan karakter membina sikap disiplin peserta didik menghasilkan beberapa hal memiliki rasa tanggung jawab, terbiasa berprilaku baik, mengembangkan dan menguatkan keyakinan, berakhlakul kharimah, (c) Faktor pendukung dari pelaksanaan pendidikan karakter dalam membina sikap disiplin peserta didik yaitu adanya guru yang berkompeten/professional, peran aktif ustadz maupun ustadzah sebagai pendidik, adanya dukungan dari keluarga atau orang tua. Sedangkan faktor penghambat yaitu kurangnya kesadaran peserta didik untuk berkarakter disiplin dan pengaruh teman bergaul.

Corresponding Author: Mia Hastarina Department Islamic Education, Faculty of Social Science Universitas Negeri Padang, Indonesia, Email: miahastarina0210@gmail.com Phone: +62895-334627690

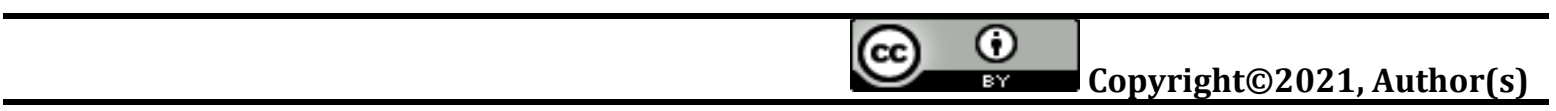

\section{Pendahuluan}

Pendidikan merupakan sebuah proses internalisasi budaya ke dalam diri seseorang dan masyarakat sehingga membuat orang dan masyarakat jadi beradab. Pendidikan bukan hanya menjadi sarana transfer ilmu pengetahuan saja, melainkan 
sebagai sarana pembudayaan dan penyaluran nilai (enkulturasi dan sosialisasi). Anak harus mendapatkan pendidikan yang menyentuh dimensi dasar kemanusiaan. Dimensi kemanusiaan itu mencakup tiga hal, diantaranya (1) afektif yang tercermin pada kualitas keimanan, ketakwaan, akhlak mulia termasuk budi pekerti luhur serta kepribadian unggul dan kompetensi estetis; (2) kognitif yang tercermin pada kapasitas pikir dan daya intelektualitas untuk menggali dan mengembangkan serta menguasai ilmu pengetahuan dan teknologi; dan (3) psikomotorik yang tercermin pada kemampuan mengembangkan keterampilan teknis, kecakapan praktis dan kompetensi kinestetis (Muslich, 2011: 69).

Menurut (Kosasih, 2013: 21) menyatakan, bahwa karakter merupakan sifat pribadi yang sudah relatif tetap di dalam diri setiap individu. Sifat tersebut melahirkan tindakan-tindakan yang positif, lahir secara spontan tanpa dibuat-buat karena sudah menjadi kebiasaan. Sehubungan dengan pengertian karakter tersebut, terlihat titik singgung antara karakter dan akhlak dalam ajaran Islam. Akhlak berasal dari kata khuluq artinya tingkah laku, perangai atau tabiat. Dalam pandangan Islam, akhlak adalah sifat yang berada dalam jiwa yang mendorong seseorang untuk melakukan perbuatan secara spontan, tanpa melalui pemikiran dan perimbangan terlebih dahulu. Akhlak adalah nilai yang telah menjadi sikap mental yang mengakar pada jiwa, lalu tampak dalam bentuk tindakan dan perilaku yang bersifat tetap, natural dan refleks.

Pendidikan karakter hal yang penting untuk dilakukan dengan melibatkan semua pihak baik rumah tangga, keluarga, sekolah maupun masyarakat luas. Oleh karena itu, hubungan dan educational networks yang terputus perlu disambung kembali. Pembentukan dan pendidikan karakter tersebut, tidak akan berhasil selama antar lingkungan pendidikan tidak ada kesinambungan dan keharmonisan. Dengan demikian, rumah tangga dan keluarga sebagai lingkungan pembentukan dan pendidikan karakter pertama dan utama harus lebih diberdayakan (Muslich, 2011: 52).

Sikap disiplin adalah kejituan atau ketepatan dalam mengikuti tata tertib atau aturan main yang telah disepakati. Kedisiplinan adalah suatu kondisi yang diciptakan melalui serangkaian proses perilaku yang menunjukkan nilai-nilai ketaatan, kepatuhan, kesetiaan, keteraturan dan ketertiban. Kedisiplinan dalam proses pendidikan sangat diperlukan karena bukan hanya untuk menjaga kondisi suasana belajar dan mengajar berjalan dengan lancar, tetapi juga menciptakan pribadi yang kuat bagi setiap siswa. Kedisiplinan membuat siswa menjadi lebih tertib dan teratur dalam menjalankan kehidupannya, serta siswa juga dapat mengerti bahwa kedisiplinan itu sangat penting bagi masa depannya kelak, karena dapat membangun kepribadian yang kokoh dan bisa diharapkan berguna bagi semua orang (Ani, 2017: 43).

Pendidikan karakter sikap disiplin yang dilaksanakan di TPQ Ihsan Muhammadiyah melalui peraturan-peraturan dengan pembiasaan yang baik. Penerapan pendidikan karakter ini diawali dengan peraturan yang ada di TPQ. 
Adapun bentuk kedisiplinan yang diterapkan diantaranya adalah datang ke TPQ Ihsan Muhammadiyah jam 18.00 atau sebelum shalat maghrib dimulai, dalam hal ini ketika ada peserta didik yang terlambat boleh masuk dengan sebuah syarat mereka disuruh membaca minimal 2 surat pendek terdahulu. Selain itu, bentuk kedisiplinan yang lain adalah melepas sandal ketika memasuki masjid, jika ada peserta didik yang mengotorinya maka mereka disuruh untuk membersihkan tempat yang dikotori tersebut. Lalu membuang sampah pada tempatnya dan duduk dengan rapi serta tidak coret-coret dibangku yang merupakan salah satu bentuk sikap disiplin yang diterapkan di TPQ Ihsan Muhammadiyah.

Berdasarkan pengamatan sementara, peneliti ingin melihat pendidikan karakter dalam membina sikap disiplin peserta didik yang harus ditanamkan pada diri peserta didik sejak dini. Untuk itulah, peneliti tertarik untuk meneliti di lokasi TPQ Ihsan Muhammadiyah dengan judul Implementasi Pendidikan Karakter Dalam Membina Sikap Disiplin Peserta Didik di Taman Pendidikan Al-Qur'an (TPQ) Ihsan Muhammadiyah Kelurahan Bandar Buat Kecamatan Lubuk Kilangan Kota Padang.

\section{Tinjauan Pustaka}

Pendidikan karakter merupakan proses pemberian tuntunan kepada peserta didik untuk menjadi manusia seutuhnya yang berkarakter dalam dimensi hati, pikir, raga, serta rasa dan karsa. Pendidikan karakter diartikan sebagai pendidikan nilai, pendidikan budi pekerti, pendidikan moral, pendidikan watak yang bertujuan mengembangkan kemampuan peserta didik untuk memberikan keputusan baik buruk dan mewujudkan kebaikan itu dalam kehidupan sehari-hari dengan sepenuh hati (Samani \& Hariyanto, 2011: 45).

Pendidikan karakter bertujuan untuk: (1) mengembangkan potensi afektif peserta didik sebagai manusia dan warga negara yang memiliki nilai-nilai budaya dan karakter bangsa, (2) mengembangkan kebiasaan dan perilaku peserta didik yang terpuji dan sejalan dengan nilai-nilai budaya karakter bangsa, (3) menanamkan jiwa kepemimpinan dan tanggung jawab peserta didik sebagai generasi penerus bangsa, (4) mengembangkan kemampuan peserta didik menjadi manusia yang mandiri, kreatif, berwawasan luas, (5) dan mengembangkan lingkungan kehidupan sekolah sebagai lingkungan belajar yang aman, jujur, persahabatan dengan rasa kebangsaan yang tinggi (Omeri, 2015: 467).

Pendidikan dibutuhkan untuk menyiapkan para generasi bangsa untuk menunjang perannya di masa yang akan datang. Dengan demikian, pendidikan menjadi sarana yang terbaik untuk menciptakan generasi baru yang tidak akan kehilangan ikatan dengan tradisi mereka sendiri, sekaligus juga tidak menjadi bodoh secara intelektual atau terbelakang dalam dunia pendidikan. Dalam rangkaian suatu proses pendidikan memiliki komponen yang sama, yang membuat proses pendidikan itu berlangsung. Pendidikan karakter yang memiliki beberapa komponen, diantaranya: 1) pendidik, 2) peserta didik, 3) kurikulum pendidikan karakter, 4) pendekatan dalam pendidikan karakter, 5) metode pendidikan karakter, 6) evaluasi 
Mia Hastarina dan Murniyetti: Implementasi Pendidikan Karakter Dalam Membina...

dalam pendidikan karakter, 7) sarana prasarana dan fasilitas pendidikan karakter (Kurniawan, 2017: 50).

Dengan menyiapkan generasi bangsa yang berkualitas, maka diperlukan sikap kedisiplinan yang baik. Disiplin merupakan suatu perbuatan dan kegiatan belajar yang dilaksanakan sesuai dengan aturan yang telah ditentukan atau direncanakan sebelumnya. Dalam sudut pandang Islam, konsep tentang disiplin sudah sangat melekat dalam setiap ajarannya. Seperti yang dilihat dengan jelas, ibadah shalat sebagai tiang agama sangat mementingkan disiplin dalam pelaksanaannya. Seperti kedisiplinan saat waktu pelaksanaannya, rukun dan adab/tata cara shalat sudah diatur dengan baik (Pasikha, 2017: 62).

Dalam ayat Al-Qur'an juga memerintahkan umat Islam untuk memiliki sikap disiplin dalam arti melaksanakan ketaatan dan perintah yang telah ditetapkan, diantaranya dalam Qur'an Surat an-Nisa/4 ayat 59:

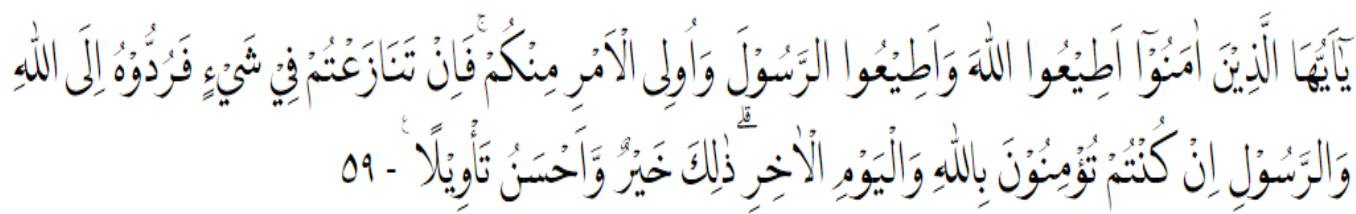

Artinya: "Wahai orang-orang yang beriman! Taatilah Allah dan taatilah Rasul (Muhammad), dan ulil amri (pemegang kekuasaan) di antara kamu. Kemudian, jika kamu berbeda pendapat tentang sesuatu, maka kembalikanlah kepada Allah (Al-Qur'an) dan Rasul (Sunnahnya), jika kamu beriman kepada Allah dan hari kemudian. Yang demikian itu, lebih utama (bagimu) dan lebih baik akibatnya" (Departemen Agama, 2006: 87).

Berdasarkan Qur'an Surat an-Nisa ayat 59 tersebut, sudah dapat dipahami bahwa disiplin hendaknya diajarkan kepada setiap peserta didik. Ada beberapa cara untuk menanamkan disiplin baik kepada anak maupun kepada siswa, di antaranya: (1) cara otoriter, cara ini orang tua maupun guru menentukan aturan-aturan dan batasan yang harus ditaati oleh anak maupun siswa. Jika mereka tidak mengikuti aturan tersebut maka mereka akan dihukum, cara ini juga menyebabkan anak merasa takut, tidak percaya diri dan sebagainya, (2) cara bebas, dengan cara ini anak dibiarkan untuk mencari dan menemukan sendiri batasan-batasan dari tingkah laku sehingga pengawasan terhadap anak menjadi longgar. Dengan demikian anak akan tumbuh kelakuan egosentrisme yang kuat sehingga mudah menimbulkan kesulitan jika menghadapi larangan yang ada dalam lingkungan sosialnya, (3) cara demokratis, cara ini lebih memperhatikan dan menghargai kebebasan anak, akan tetapi kebebasan yang tidak mutlak dan bimbingan yang penuh pengertian antara kedua belah pihak. Dengan demikian anak akan tumbuh dengan rasa tanggung jawab dan bisa memupuk rasa kepercayaan dirinya dengan baik sesuai dengan aturan yang berlaku (Pasikha, 2017: 63).

Menurut (Choirul Anam \& Suharningsih, 2014: 475), mengatakan bahwa cara mendidik dan membentuk karakter disiplin pada santri diantaranya: 1) keteladanan, 
merupakan komponen yang sangat penting dalam upaya pembinaan dan membentuk sikap disiplin peserta didik, peserta didik menjadikan guru sebagai patokannya dalam cara berpakaian, mematuhi tata tertib dan sebagainya, 2) komunikasi, hal ini perlu dilakukan untuk mempererat hubungan antara guru dengan peserta didik, komunikasi dapat dilakukan dengan cara sosialisasi tata tertib kepada peserta didik dengan menempelkan peraturan pada mading-mading dan pemberian buku panduan kepada peserta didik yang berisi kewajiban, keharusan dan larangan, 3) pembiasaan, sikap disiplin terbentuk karena pembiasaan, demikian juga dengan kepribadian yang tertib, teratur dan patuh perlu dibiasakan dan dilatih, 4) nasihat dan teguran, tujuannya menghindari peserta didik dari perbuatan yang melanggar tata tertib, 5) pemberian penghargaan (reward) dan sanksi/hukuman (punishment), pemberian sanksi/hukuman diberikan kepada peserta didik yang melanggar tata tertib sedangkan pemberian reward diberikan kepada peserta didik yang berprestasi, artinya pemberian tidak hanya berupa barang, tapi sekolah juga memberikan pujian dengan cara diumumkan nama-nama peserta didik yang berprestasi.

Dalam proses pelaksanaan pendidikan karakter, membutuhkan sebuah proses evaluasi sebagai penilaian baik buruknya pelaksanaan pendidikan karakter. Evaluasi memegang peranan yang sangat penting dan menjadi suatu keharusan. Kegiatan dalam proses belajar mengajar baik sederhana maupun komplek sangat membutuhkan sebuah evaluasi. Sebelum melaksanakan evaluasi guru perlu mengetahui langkah-langkah/prosedur yang sistematis agar evaluasi dapat diteliti secara menyeluruh dan relevan. Terdapat dua aspek penting dari istilah evaluasi, diantaranya : pertama, evaluasi merupakan suatu proses yang sistematis.

Suatu proses berarti evaluasi bukanlah suatu kegiatan yang final, melainkan kegiatan yang berkelanjutan. Artinya evaluasi dilakukan selanjutnya disertai dengan tindakan yang lain. Sistematis berarti langkah-langkah dalam melaksanakan evaluasi disusun menurut prosedur tertentu atau pedoman yang telah ditentukan sebelumnya, dan aspek yang kedua evaluasi berarti kemampuan yang dicapai oleh siswa dalam pengajaran. Dalam pengajaran sebelumnya ada sebuah penegasan tentang kemampuan-kemampuan yang perlu dimiliki oleh siswa setelah proses pengajaran selesai. Artinya tujuan-tujuan pengajaran telah dirumuskan secara operasional sebelumnya, hingga dapat diundur tanpa dirumuskan dengan jelas tujuan operasional pengajaran (Joesmani, 1988: 19).

Beberapa faktor pendukung pelaksanaan pendidikan karakter dalam membina sikap disiplin yaitu: (1) dari segi keadaan keluarga, keluarga merupakan tempat yang paling utama dalam membina kepribadian dan menjadi salah satu faktor yang sangat penting. Keluarga mempengaruhi dan menentukan perkembangan kepribadian seseorang dikemudian hari. Keluarga dapat menjadi faktor pendukung maupun penghambat dalam pembinaan perilaku disiplin. Keluarga yang baik merupakan keluarga yang menerapkan norma-norma secara baik. Sikap ini akan tampak dalam kesadaran akan norma-norma yang berlaku dalam masyarakat, (2) lingkungan sekolah, pembinaan disiplin di sekolah ditentukan oleh keadaan sekolah tersebut. 
Mia Hastarina dan Murniyetti: Implementasi Pendidikan Karakter Dalam Membina...

Keadaan sekolah dalam hal ini adalah ada atau tidaknya sarana-sarana yang diperlukan bagi kelancaran proses belajar mengajar, (3) lingkungan masyarakat, masyarakat menjadi lingkungan yang lebih universal dari pada sekolah dan keluarga yang juga turut menentukan berhasil atau tidaknya pembinaan sikap disiplin (Pridayani Yusmarlina, 2020: 19).

Sedangkan faktor penghambat pendidikan karakter dalam membina sikap disiplin, diantaranya: (1) sekolah yang kurang menerapkan disiplin, hal ini akan menimbulkan kurangnya rasa tanggung jawab peserta didik ketika melaksanakan tugas-tugas yang ada di sekolah, (2) teman sepergaulan, anak yang bergaul dengan anak yang baik maka perilakunya dapat menjadi baik dalam berinteraksi sehari-hari dan begitupun sebaliknya, (3) kurangnya kesadaran dan sikap orang tua yang berlebihan, anak yang dimanjakan oleh orang tuanya akan cenderung kurang bertanggung jawab dan takut menghadapi tantangan dan kesulitan yang akan menimpanya, begitu pula sebaliknya anak yang sikap orang tuanya otoriter dia akan menjadi penakut dan tidak berani mengambil sebuah keputusan, (4) keluarga yang tidak harmonis, anak yang tumbuh dari keluarga yang tidak harmonis/broken home ia akan selalu membiasakan dirinya untuk selalu mengganggu orang dan kurang disiplin, (5) latar belakang kebiasaan dan budaya, budaya dan tingkat pendidikan orang tua juga memiliki pengaruh terhadap kedisiplinan peserta didik. anak yang hidup di keluarga yang baik dan tingkat pendidikan orang tua yang bagus ia akan cenderung berprilaku yang baik pula (Mulyasa, 2013: 26).

Taman Pendidikan Al-Qur'an adalah sebuah lembaga atau sekolah yang berupaya mendidik anak-anak dari usia 7-12 tahun atau usia masuk Sekolah Dasar. Sehingga mampu membaca, memahami dan mengamalkan Al-Qur'an. Adapun tujuan dari pendidikan Taman Pendidikan Al-Qur'an yaitu: (1) membantu mengembangkan potensi anak ke arah pembentukan sikap/afektif, pengetahuan/kognitif dan keterampilan/psikomotor keagamaan melalui pendekatan yang disesuaikan dengan lingkungan dan taraf perkembangan anak, berdasarkan tuntunan yang ada di dalam Al-Qur'an dan sunnah Rasulullah, (2) mempersiapkan anak agar mampu mengembangkan sikap, pengetahuan dan keterampilan keagamaan yang telah dimiliki melalui program lanjutannya (Dedi Setiawan dkk, 2017: 173).

\section{Metodologi}

Penelitian ini menggunakan penelitian kualitatif, yakni penelitian langsung terjun kelapangan mendeskripsikan fenomena, informasi, dan data yang ada di lapangan terkait degan apa yang telah dilakukan. Metode penelitian yang digunakan yaitu metode observasi, metode wawancara dan metode dokumentasi. Adapun yang menjadi informan dalam penelitian diantaranya: a) pengurus TPQ Ihsan Muhammadiyah, b) kepala dan guru TPQ Ihsan Muhammadiyah, c) peserta didik TPQ Ihsan Muhammadiyah, d) dan orang tua dari peserta didik TPQ Ihsan Muhammadiyah. Teknik analisis data dalam penelitian ini menggunakan deduktif, keterangan-keterangan yang bersifat umum menjadi pengertian khusus yang 
terperinci, baik dari pengetahuan yang diperoleh dari lapangan maupun kepustakaan. Teknik pengabsahan data meliputi ketekunan dan triangulasi.

\section{Hasil dan Pembahasan}

\section{Pelaksanaan Pendidikan Karakter Dalam Membina Sikap Disiplin Peserta Didik di TPQ Ihsan Muhammadiyah Kota Padang}

Pelaksanaan pendidikan karakter dalam membina sikap disiplin bertujuan membantu seorang individu (peserta didik) dalam mengembangkan pandangan hidup yang Islami sesuai dengan ajaran dan nilai-nilai Islam dan diaplikasikan ke dalam kehidupan sehari-hari. Agar pandangan hidup Islami tersebut dapat diamalkan dengan baik, tentu dibutuhkan proses yang harus dilakukan agar pembinaan karakter disiplin benar-benar tertanam di tempat belajar peserta didik (TPQ). Ustadz maupun Ustadzah khususnya harus bekerja sama secara optimal agar karakter sikap disiplin dapat terlaksana secara maksimal.

Dari paparan wawancara dengan kepala TPQ Ihsan Muhammadiyah, Ustadz Marjoni, bahwasanya: "Dalam pembinaan sikap disiplin peserta didik dilakukan dengan mengadakan peraturan-peraturan yang diterapkan dalam TPQ ini sehingga hal ini akan menjadi patokan sendiri bagi peserta didik untuk melatih mereka lebih disiplin dan tidak melakukan sebuah pelanggaran. Sehingga para peserta didik akan terbiasa melakukan sebuah kebiasaan yang positif yang dapat mereka amalkan dalam kehidupannya."

Agar pendidikan karakter dapat diaplikasikan di TPQ Ihsan Muhammadiyah, maka dibutuhkan dukungan dari semua pihak baik ustadz/ustadzah maupun dari warga TPQ Ihsan Muhammadiyah yang mempunyai fungsi dan peran masing-masing, yang mana peranan tersebut saling mempengaruhi satu sama lainnya. Juga dengan menerapkan beberapa peraturan dalam membina sikap kedisiplinan peserta didik TPQ Ihsan Muhammadiyah.

Hal ini juga dikatakan oleh Ustadzah Azizah selaku guru di TPQ Ihsan Muhammadiyah, "Selain dengan beberapa peraturan kita juga memberikan peringatan, teguran dan hukuman/sanksi. Selain itu juga bisa dengan memberikan contoh sikap yang baik/keteladanan yang baik, pemberian reward/hadiah dan pemberian nasehat itu juga termasuk cara kita membina sikap kedisiplinan peserta didik."

Dari informasi tersebut dapat dijelaskan pelaksanaan pendidikan karakter dalam membina sikap kedisiplinan peserta didik sebagai berikut: 1) Sanksi atau teguran peringatan, dalam membina sikap kedisiplinan peserta didik, ustadz maupun ustadzah melakukan tindakan dengan memberikan teguran, peringatan dan sanksi. Adapun bentuk hukumannya yaitu menghafalkan minimal dua surat pendek, menghafalkan doa sehari-hari, berdzikir sambil berdiri, dan membersihkan ruangan belajar. Selain itu, ustadz/ustadzah juga selalu memberitahukan perilaku peserta didik kepada kedua orang tuanya, supaya orang tuanya dapat menasehati anaknya, 2) 
Mia Hastarina dan Murniyetti: Implementasi Pendidikan Karakter Dalam Membina...

Keteladanan, perilaku guru sangat berperan penting dalam ukuran keteladanan peserta didik. Memberikan contoh yang baik kepada peserta didik di TPQ Ihsan Muhammadiyah dalam kehidupan sehari-hari yaitu dengan menggunakan kata-kata yang sopan santun, ikut sholat berjamaah di masjid dan sebagainya. Karena apapun yang dilakukan oleh ustadz maupun ustadzah akan dilihat dan ditiru oleh peserta didiknya, 3) Pemberian reward/hadiah, peserta didik yang senantiasa mematuhi peraturan dengan baik akan mendapatkan hadiah berupa pujian. Hal ini dilakukan agar peserta didik menjadi termotivasi dalam menerapkan kedisiplinan dalam setiap kegiatan apapun di TPQ Ihsan Muhammadiyah, 4) Pemberian nasihat, teknik pemberian nasihat ini dilakukan dengan dua cara yaitu: a) secara individu, yaitu seorang ustadz/ustadzah membina dengan memberikan nasihat kepada satu peserta didik yang melanggar peraturan dengan cara menjelaskan tentang pentingnya sikap disiplin dan tidak mengulangi kesalahan yang diperbuatnya, b) secara kelompok, yaitu setiap ustadz/ustadzah ketika sedang melaksanakan kegiatan proses belajar mengajar (PBM) memberikan nasihat dan arahan secara bersama-sama. Hal ini dilakukan ketika peserta didik banyak yang melakukan pelanggaran.

\section{Evaluasi Pendidikan Karakter Dalam Membina Sikap Disiplin Peserta Didik di TPQ Ihsan Muhammadiyah Kota Padang}

Evaluasi memegang peranan yang sangat penting dalam hal apapun terutama dalam proses pembelajaran. Di TPQ Ihsan Muhammadiyah, kegiatan evaluasi ini dilaksanakan pada saat rapat bersama yang dilakukan satu kali dalam seminggu. Serta melibatkan orang tua apabila diperlukan.

Hal tersebut sesuai dengan pernyataan Bapak Marjoni selaku kepala TPQ sebagai berikut: "Kalau ada permasalahan pada peserta didik, saya dan segenap guru melakukan rapat. Yang mana rapat ini menjadi salah satu program wajib kami dari para guru sebagai evaluasi tingkah laku peserta didik maupun kegiatan lainnya. Program ini kami namakan "brieving". Disini kami selalu mengevaluasi, seperti bagaimana karakter anak didik kami, apakah mengalami peningkatan yang bagus atau belum dan kekurangan-kekurangan kegiatan seminggu sebelumnya dan apa yang harus kita lakukan minggu berikutnya sedangkan untuk mengevaluasi peserta didik kami pihak guru akan memberikan surat peringatan, buku kasus dan melakukan diskor apabila pelanggaran peraturannya sudah sering terjadi. Dan buku kasus itu juga akan kami perlihatkan kepada orang tuanya, supaya orang tuanya juga tau bagaimana perilaku anaknya selama mengikuti kegiatan proses belajar mengajar."

Selain dengan peraturan, faktor keberhasilan dalam membina sikap kedisiplinan juga dari nasihat-nasihat yang diberikan oleh ustadz/ustadzah. Hal ini sebagaimana diungkapkan oleh Ustadz Novra, beliau mengatakan bahwa: "Dengan pemberian nasihat-nasihat kepada peserta didik akan menjadikan mereka lebih bertanggung jawab, lebih memahami arti kedisiplinan dan berprilaku yang baik dan juga nantinya ini akan menjadi patokan dasar dalam kehidupannya sehari-hari. Selain 
itu, juga sebagai perbaikan untuk memperkuat dan membangun perilaku peserta didik yang multikultural untuk menjadi peserta didik yang bermartabat."

Berdasarkan keterangan tersebut, dapat dijelaskan bahwa terdapat banyak hasil pendidikan karakter dalam membina sikap kedisiplinan peserta didik apabila dilakukan dengan sebaik mungkin.

Pendapat ini dikuatkan oleh Ustadzah Putri, beliau mengatakan: "Hasil dari pendidikan karakter dalam membina sikap disiplin peserta didik ada beberapa menurut saya kak diantaranya: a) peserta didik lebih mendominankan rasa tanggung jawab dalam dirinya masing-masing, sehingga hal ini akan membuat peserta didik lebih mandiri dalam melakukan tugasnya, b) menumbuhkan minat pada peserta didik sebagai generasi muda untuk menambah pengetahuan terutama pengetahuan keagamaan, c) menanamkan dan memiliki rasa cinta terhadap Al-Qur'an (membaca, memahami isinya dan mengamalkan ajarannya), d) dapat menyesuaikan atau memposisikan dirinya dalam lingkungan bermasyarakat, e) penyaluran untuk mendalami pendidikan agama ke lembaga pendidikan yang lebih tinggi, f) pengembangan potensi peserta didik TPQ Ihsan Muhammadiyah agar berprilaku baik, g) dan membawa peserta didik agar memiliki karakter yang baik dan kedisiplinannya ke dalam lingkungan masyarakat dan tempat belajaranya sehingga ini akan menjadikan dirinya sebagai pribadi yang berkualitas."

\section{Faktor Pendukung dan Penghambat Pendidikan Karakter Dalam Membina Sikap Disiplin Peserta Didik di TPQ Ihsan Muhammadiyah Kota Padang}

Berdasarkan penelitian dalam pelaksanaan pendidikan karakter dalam membina sikap disiplin peserta didik di Taman Pendidikan Al-Qur'an (TPQ) Ihsan Muhammadiyah Kelurahan Bandar Buat Kecamatan Lubuk Kilangan Kota Padang bahwa terdapat faktor pendukung dan penghambat dalam proses membina sikap disiplin peserta didik.

Beberapa faktor pendukung yang dikatakan oleh Ustadz Marjoni, yaitu: "Dalam penerapan karakter disiplin peserta didik, tentu ada faktor pendukungnya. Yang pertama yaitu dari segi SDM (Sumber Daya Manusia) yang berkompeten, rata-rata kami para guru disini seorang pendidik/pengajar juga di sekolah-sekolah. Yang kedua, adanya aturan yang ketat, ini ditujukan untuk peserta didik supaya mereka juga tidak semena-mena melakukan pelanggaran dan melatih mereka untuk lebih bertanggung jawab serta disiplin. Yang ketiga, faktor keluarga, bagi bapak keluarga merupakan salah satu faktor yang mempengaruhi pendidikan karakter bagi si anak dan keluargalah tempat pendidikan pertama bagi si anak.

Lingkungan juga dapat mempengaruhi karakter pada anak. Sedangkan untuk faktor penghambat dalam pembinaan karakter disiplin ini yaitu peserta didik yang melanggar peraturan dan tidak mengabaikan SP (Surat Peringatan) yang sudah diberikan guru, lalu dari segi latar belakang peserta didik, peserta didik berasal dari latar belakang yang berbeda, maka pola tingkah lakunya pun berbeda. Disini posisi 
Mia Hastarina dan Murniyetti: Implementasi Pendidikan Karakter Dalam Membina...

lingkungan keluarga sangat berperan penting sekali dalam proses pembinaan karakter disiplin, kemandirian serta rasa tanggung jawab peserta didik."

Dengan demikian, adapun faktor pendukung dan penghambat yang diungkapkan oleh Ustadzah Mirathesa ketika pelaksanaan pendidikan karakter dalam membina sikap disiplin peserta didik di TPQ Ihsan Muhammadiyah, mengatakan: "Faktor pendukungnya seperti adanya dorongan dari dalam diri peserta didik yaitu dikarenakan adanya kesadaran untuk disiplin, ada dorongan dari luar seperti adanya perintah, sanksi, larangan kak. Dan faktor penghambatnya bisa berasal dari sikap orang tua yang selalu memanjakan anaknya, hal ini akan mengakibatkan mereka cenderung kurang bertanggung jawab dan takut menghadapi tantangan dan tidak mau mencoba sesuatu yang baru, bergaul dengan teman yang kurang disiplin karena akan mempengaruhi peserta didik yang lainnya untuk meniru perbuatan temannya."

Dari penjelasan tersebut, peneliti dapat menganalisis bahwa faktor pendukung pendidikan karakter dalam membina sikap disiplin peserta didik di Taman Pendidikan Al-Qur'an (TPQ) Ihsan Muhammadiyah adalah adanya ustadz/ustadzah yang sangat aktif, berkompeten, bekerja sama dalam mendidik pendidikan karakter disiplin peserta didik baik itu di dalam pembelajaran maupun di luar pembelajaran, karena hal tersebut sangat penting dalam mendidik karakter disiplin. Hal ini membuat peserta didik akan terus merasa semangat dalam belajar dengan berkarakter disiplin. Selain peran aktif dari guru-guru, faktor pendukung lainnya yaitu adanya dukungan dari keluarga atau orang tua, keluarga tempat pendidikan utama bagi si anak, dengan adanya dukungan dari orang tua/keluarga akan berpengaruh dan dapat menentukan perkembangan peserta didik dalam berkarakter disiplin yang baik.

Selain faktor pendukung, juga terdapat faktor penghambat dalam pelaksanaan pendidikan karakter dalam membina sikap disiplin peserta didik di TPQ Ihsan Muhammadiyah, salah satunya kurangnya kesadaran peserta didik untuk berkarakter disiplin. Para peserta didik masih banyak yang terlambat ketika datang ke TPQ Ihsan Muhammadiyah, masih ada yang tidak melaksanakan shalat maghrib dan shalat isya berjamaah di masjid, masih terdapatnya peserta didik yang tidak memakai seragam dan ketika kegiatan proses belajar mengajar sedang berlangsung masih ada yang bermain sendiri, mengobrol dengan temannya dan membuat kegaduhan.

Untuk mengatasi faktor penghambat pendidikan karakter dalam membina sikap disiplin peserta didik di TPQ Ihsan Muhammadiyah yaitu dilakukan dengan cara pemberian motivasi akan pentingnya berkarakter disiplin serta peserta didik harus mengatur waktu dengan baik agar lebih disiplin lagi

\section{Simpulan}

Berdasarkan temuan penelitian maka kesimpulan yang didapatkan tentang implementasi pendidikan karakter dalam membina sikap disiplin peserta didik di Taman Pendidikan Al-Qur'an (TPQ) Ihsan Muhammadiyah Kelurahan Bandar Buat Kecamatan Lubuk Kilangan Kota Padang adalah: 
1. Pelaksanaan pendidikan karakter dalam membina sikap disiplin peserta didik di Taman Pendidikan Al-Qur'an (TPQ) Ihsan Muhammadiyah, dilakukan dengan beberapa pelaksanaan diantaranya peraturan yang harus ditaati, pemberian nasihat, pemberian hadiah/reward dan sanksi guna menunjang keberhasilan kedisiplinan peserta didik.

2. Dalam evaluasi pendidikan karakter membina sikap disiplin peserta didik di TPQ Ihsan Muhammadiyah menghasilkan beberapa hal diantaranya memiliki rasa tanggung jawab, menjadi terbiasa dengan berprilaku yang baik, mengembangkan dan menguatkan keyakinan peserta didik, berakhlakul kharimah, menanamkan jiwa leadership kepada peserta didik, menjadikan peserta didik lebih mandiri dan mengembangkan lingkungan kehidupan di TPQ sebagai lingkungan yang aman dan jujur.

3. Faktor pendukung dari pelaksanaan pendidikan karakter dalam membina sikap disiplin peserta didik di TPQ Ihsan Muhammadiyah yaitu adanya guru yang berkompeten/professional, peraturan yang ketat, peran aktif ustadz maupun ustadzah sebagai pendidik, pengajar dan pembimbing, adanya dukungan dari keluarga atau orang tua. Sedangkan faktor penghambat pendidikan karakter dalam membina sikap disiplin peserta didik yaitu kurangnya kesadaran peserta didik untuk berkarakter disiplin dan pengaruh teman bergaul atau bergaul dengan teman yang kurang disiplin.

\section{Referensi}

Alfath, Khairuddin. (2020). Pendidikan Karakter Disiplin Santri di Pondok Pesantren Al-Fatah Temboro. Jurnal Komunikasi dan Pendidikan Islam. 9(1).

Ani, Endriani. (2017). Hubungan Antara Keharmonisan Keluarga Dengan Sikap Disiplin Siswa. Jurnal Paedagogy: 4(2).

Choirul Anam \& Suharningsih. (2014). Model Pembinaan Disiplin Santri (Studi Kasus Pondok Pesantren Darul Fiqhi Kabupaten Lamongan. Jurnal Kajian Moral dan Kewarganegaraan. 2(2).

Dedi Setiawan, Amir Rusdi, Vinny Aisyahlani Putri. (2017). Peran TPA dalam Penyelenggaraan Pendidikan Al-Qur'an di Masjid Al-Fattah Palembang. Jurnal Ilmiah PGMI. 3(2).

Joesmani. (1988). Pengukuran dan Evaluasi dalam Pengajaran. Departemen Pendidikan dan Kebudayaan: Direktorat Jendral Pendidikan Tinggi Jakarta.

Kurniawan, Syamsul. (2017). Pendidikan Karakter: Konsepsi \& Implementasinya secara Terpadu di Lingkungan Keluarga, Sekolah, Perguruan Tinggi dan Masyarakat. Yogyakarta: Ar-Ruzz Media.

Kosasih, Ahmad. (2013). Pendidikan Karakter: Sebuah Refleksi Pendekatan dalam Ilmu Humaniora. Sukabina Press: Padang.

Masnur, Muslich. (2011). Pendidikan Karakter: Menjawab Tantangan Krisis Multidimensional. Jakarta: PT Bumi Aksara.

Mulyasa. (2013). Manajemen Pendidikan Karakter. Jakarta: Sinar Grafika Offset. 
Mia Hastarina dan Murniyetti: Implementasi Pendidikan Karakter Dalam Membina...

Omeri, Nopan. (2015). Pentingnya Pendidikan Karakter dalam Dunia Pendidikan. Jurnal Manajer Pendidikan. 9(3).

Pasikha, Nok. (2017). Implementasi Manajemen Kelas dalam Mengatasi Masalah Disiplin Siswa. Jurnal Dialektika Jurusan PGSD 7(1). ISSN: 2089-3876.

Samani, Muchlas \& Hariyanto. (2011). Konsep dan Model Pendidikan Karakter. Bandung: PT Remaja Rosdakarya. 